\title{
Rereading Bayle
}

\author{
E. A. Terenteva
}

For citation: Terenteva E. A. Rereading Bayle. Vestnik of Saint Petersburg University. History, 2020, vol. 65, iss. 1, pp.329-338. https://doi.org/10.21638/11701/spbu02.2020.120

In the first decades of the twenty-first century there has been a notable surge of scholarly interest in the problems of intellectual history, the issues of the Scientific Revolution in both Natural sciences and Humanities which still stay ahead of the curve. Such renowned researchers as P. Dear, S. Shapin, D. Wootton, and others are contributing to the study of changes in the minds of European intellectuals including their methods and their philosophical comprehension of the world. The monograph by Mara van der Lugt dedicated to the works of an eminent philosopher and writer of the early Enlightenment Pierre Bayle (1647-1706) is a major contribution to the vast Baylean studies which amount to hundreds of papers. The heritage of Bayle is put into political, religious, intellectual, and methodological contexts, including the complicated system of links and relations within the European Republic of Letters. The researcher suggests "a new way of reading Bayle", which enables to raise and analyze a wide range of problems relating to Bayle's "Historical and Critical Dictionary". Another interesting methodological approach is the use of the figure of Bayle's friend-antagonist Pierre Jurieu (1637-1713) as a sort of a semantic pivot, which simplifies the process of structuring and analyzing the enormous textual material. But, however solid and grounded the monograph is, it requires a number of critical comments given in the present review.

Keywords: intellectual history, history of science, Bayle, Jurieu, Enlightenment, Republic of Letters, philosophy.

\section{Перечитывая Бейля}

\section{E. А. Терентьева}

Для цитирования: Terenteva E. A. Rereading Bayle // Вестник Санкт-Петербургского университета. История. 2020. Т. 65. Вып. 1. С. 329-338. https://doi.org/10.21638/11701/spbu02.2020.120

Для первых десятилетий XXI в. характерен заметный рост интереса к проблемам интеллектуальной истории, причем вопросы, связанные с научной революцией, сохраняют в рамках этого направления научной мысли лидирующие позиции. XVII в. принес перемены как в область точных и естественных наук, так и в гуманитарное знание. Изучением изменений, происходивших в умах европейских интеллектуалов той эпохи, включая их методы и философское осмысление мира, занимаются сегодня такие признанные ученые, как П.Деар, С.Шейпин, Д. Вуттон и другие. Монография Мары

Ekaterina A. Terenteva - PhD in History, Assistant Professor, St. Petersburg State University of Telecommunication, 22, pr. Bolshevikov, St. Petersburg, 193232, Russian Federation; e.a.terenteva@bk.ru

Екатерина Анатольевна Терентьева - канд. ист. наук, доц., Санкт-Петербургский государственный университет телекоммуникаций, Российская Федерация, 193232, Санкт-Петербург, пр. Большевиков, 22; e.a.terenteva@bk.ru

(c) Санкт-Петербургский государственный университет, 2020 
ван дер Лугт «Бейль, Жюрье и “Исторический и критический словарь”», посвященная трудам выдающегося философа и писателя эпохи раннего Просвещения Пьера Бейля (1647-1706), вносит вклад не только в обширные «бейлеанские» исследования, число которых исчисляется сотнями. Наследие П.Бейля в ее работе помещено в политический, религиозный, интеллектуальный и методологический контексты, включая сложную систему связей, существовавшую в рамках европейской «Республики ученых» конца XVII в. Мара ван дер Лугт предлагает «новый способ читать Бейля», позволяющий ставить и анализировать широкий спектр проблем, связанных с главным произведением Бейля, «Историческим и критическим словарем». Другой ее интересный методологический прием заключается в использовании фигуры друга-антагониста П. Бейля, Пьера Жюрье (1637-1713), как одного из смысловых стержней исследования, что в определенной степени упрощает структурирование и анализ огромного текстового материала. Эта неохватность существующего наследия философа является одним из факторов, принципиально не позволяющих создать всеобъемлющую работу о Бейле и вынуждающих исследователей так или иначе ограничивать свой предмет. И какой бы основательной и серьезной ни была монография М. ван дер Лугт, она вызывает ряд критических замечаний, которые даны в настоящей рецензии.

Ключевые слова: интеллектуальная история, история науки, Бейль, Жюрье, Просвещение, Республика ученых, французская протестантская эмиграция, философия.

Close association between philosophy and history is undoubtedly a sort of axiom in the field of humanities. Dealing with the philosophical constructions and systems of views of any epoch requires deep knowledge of its socio-cultural and political contexts, as well as the intellectual background and the succession of perspectives, hence a certain difficulty of drawing a strict boundary between historical and historical-philosophical research. With regards to European Humanities in the early modern epoch the picture is even more complex as the system of knowledge in its modern version was only emerging then, and the boundaries between philosophy, history and social thought were vague and indistinct ${ }^{1}$. Despite the rise of rationalism in the course of the seventeenth century, the situation had changed little, and social and historical science, scientia civilis ${ }^{2}$ remained inseparable. This phenomenon manifested itself in the emergence of works encompassing diverse problems of humanities, such as the "Historical and Critical Dictionary" of Pierre Bayle (1647-1706), disguising subtle philosophy as history.

It is agreed that Bayle was a key, though controversial, figure in the history of the early Enlightenment. Although the studies into Bayle amounts to hundreds of works, very few of them qualify as exhaustive considering the scope of the material and the complicacy and the ambiguity of Bayle's views and interests. The bright and daring creation of Mara van der Lugt "Bayle, Jurieu, and the Dictionnaire historique et critique" is one of these few researches.

The publication of Van der Lugt's doctoral thesis ${ }^{3}$ has provoked a vivid interest inside the global scholarly community pertaining to the humanities. Over the three years which

${ }^{1}$ Concerning the specifics of the humanities in the sixteenth and seventeenth centuries see, for example: Terenteva E. A. The early modern genre of cabinet in the heritage of French erudite // Vestnik of Saint Petersburg University. History. 2018. Vol. 63, iss. 1. P. 80-92.

2 Ivanova I. "Istoriia idei" i "grazhdanskaia nauka": granitsy distsiplinarnosti v rannee Novoe vremia // Nauki o cheloveke: istoriia distsiplin. Moscow, 2015. P. 53.

3 Van der Lugt M. Bayle, Jurieu and the Dictionnaire Historique et Critique. Oxford, 2016. 
have passed since its appearance, a number of various reviews have emerged in different scholarly editions all over the world ${ }^{4}$, such as the brilliant masterpiece by Antony McKenna ${ }^{5}$, the thoughtful and sophisticated analysis by Karen Collis ${ }^{6}$, or the witty and philosophical creation of Richard Whatmore ${ }^{7}$. The undiminishing scholarly interest in the monograph shows at the same time the relevance of the chosen topic and the depth of the research undertaken as the reviews are mostly complimentary. However, some criticism has been expressed of the modes of interpretation and the methodology used by Mara van der Lugt $^{8}$ as well as of some smaller particular subjects. ${ }^{9}$ Yet there are still several commentaries concerning the monograph - both positive and critical - which have not been articulated, so this review will dwell on those issues, which are, to my mind, quite essential, but have not been addressed in the existing reviews.

The fascinating and controversial early modern era, being the cradle of our contemporary Western civilization, is not likely to stop attracting researchers' attention. And before passing to more profound issues, it should be noted that several problems chosen byAnd before passing to more profound issues, it should be noted that a number of problems selected by Mara van der Lugt as markers of Bayle's worldview showcasing the potential of her method ${ }^{10}$, remain significant in the twenty-first century. Thus, problems of tolerance, which has doubtlessly become one of the main values of the Western culture and constitutes part of its philosophical and ideological foundations, sound very topical. Therefore, the work of Mara van der Lugt appears to be very relevant and is connected not only with the history of science and the history of ideas but with the philosophical grounds of the modern liberal-democratic philosophy, which are, similarly to many postmodernist ideas anchored in the intellectual processes in the seventeenth-century Europe. And in this regard the book would be helpful to anyone interested in the philosophical problems of contemporary European societies. The concepts of pacifism, calumny, insult of dignity and its consequences, or even the notion and the specifics of the Republic of Letters may be interpreted in a similar way.

${ }^{4}$ Bernier J. Mara van der Lugt. Bayle, Jurieu, and the Dictionnaire Historique et Critique // Erudition and the Republic of Letters. 2018. Vol.3, iss. 2. P.232-234; Green M. Mara Van Der Lugt. Bayle, Jurieu, and the 'Dictionnaire Historique et Critique' // Renaissance Studies. 2017. Vol.32, iss. 4. P.667-669; Irwin K. Bayle, Jurieu, and the Dictionnaire Historique et Critique by Mara van der Lugt (review) // Journal of the History of Philosophy. 2017. Vol.55, no. 3. P.547-548; Matytsin A. Mara van der Lugt, Bayle, Jurieu, and the Dictionnaire Historique et Critique // H-France Review. Vol. 17. No. 16. P. 1-5; Whealan R. Review: Bayle, Jurieu, and the "Dictionnaire historique et critique" by Mara van der Lugt // The Modern Language Review. 2017. Vol. 112, no. 2. P. 508-509.

5 McKenna A. Bayle, Jurieu, and the "Dictionnaire Historique et Critique". By Mara van der Lugt // History. 2017. Vol. 102, iss. 352. P. 696-699.

${ }^{6}$ Collis K. Bayle, Jurieu, and the Dictionnaire historique et critique, by Mara van der Lugt // Intellectual History Review. 2018. Vol.28, no. 3. P. 451-460.

7 Whatmore R. Bayle, Jurieu and the Dictionnaire Historique et Critique, by Mara van der Lugt // The English Historical Review. 2018. Vol. 133, iss. 561. P. 443-444.

${ }^{8}$ McKenna A. Bayle, Jurieu, and the 'Dictionnaire Historique et Critique'. By Mara van der Lugt // History. 2017. Vol. 102, iss. 352. P. 698.

9 Collis K. Bayle, Jurieu, and the Dictionnaire historique et critique, by Mara van der Lugt // Intellectual History Review. 2018. Vol.28, no. 3. P. 451-460.

${ }_{10}$ Mara van der Lugt herself underlines that her monograph "has been a test case for the method outlined in the first chapter" (Van der Lugt M. Bayle, Jurieu and the Dictionnaire Historique et Critique. P. 248). 
But first and foremost "Bayle, Jurieu, and the Dictionnaire historique et critique" is undoubtedly the result of a profound and meticulous academic study of an impressive number of various seventeenth-century texts put into the historical, cultural and philosophical contexts. It is also, as we may conclude from some statements of the author, probably the first step in a large-scale research project devoted to rereading the oeuvre of Pierre Bayle on the basis of a new methodological approach developed by Dr Van der Lugt. Concerning its methodology, her work is quiet topical and belongs to the current trend of the "new intellectual history" with its concentration on texts, their structure, language, etc., at the same time being part of the "new comparative history"11, the trend in the modern historical science connected with the contextualization. Both tendencies imply revising the views on the intellectual processes in the early modern Europe established in the humanities in the last quarter of the twentieth century, which is - one way or another - also realized in the monograph in question.

Placing a rich historiographical essay in the Introduction and sketching not only the existing views on Bayle and his legacy, but also main methodological approaches to its study, Mara van der Lugt revises the historiographical traditions of interpreting Bayle and endeavors to find a "third way", combining features of the polar views and adding some novelties of her own. Thus the main argument of the study is the suggestion of a new method, or "a new way of reading Bayle"12.

Van der Lugt's aspiration of taking no side in the existing hermeneutical debates concerning Bayle seems to imply broad research perspectives. She tries to stay unbiased and claims that "there is no 'perfect' way of reading Bayle"13. Having critically enumerated different ways of "reading Bayle", she also amplifies the list with a "straussian" suggestion that Bayle should be read "with Bayle" 14 . She criticizes the approach of the "hermeneutics of suspicion" which perceives Bayle as an author who hides his own position behind different masks. But the statement that "there is the danger of over-interpretation", of "reading too much into the Dictionnaire, and turning Bayle into something that he was not" 15 demands a more readable author's position. Her own manner of interpretation of the texts is, on the one hand, irreproachable: Van der Lugt analyzes the text meticulously and thoroughly; she does not attempt to ascribe any interpretations to vague passages. For example, she underlines the existing impossibility to determine which voice of the "voices" used by Bayle in his polylogic discussions is heard at a particular moment, or traces different shades of the use of the pronoun 'I' in the Dictionary; such conclusions require a deep and critical penetration into the source as well as research impartiality. On the other hand, sometimes the indeterminacy of her position (which has already been pointed out to Van der Lugt in some of the reviews on her book ${ }^{16}$ ), whether it is researcher's modesty or caution, prevents her from drawing any concrete conclusion. And this trait seems to become part of her method, which she chooses to call "the hermeneutics of suspension"17.

${ }^{11}$ Repina L.P. Konteksty intellektual'noi istorii // Dialog co vremenem - Dialogue with time. 2008. No.25-1. P.6.

12 Van der Lugt M. Bayle, Jurieu and the Dictionnaire Historique et Critique. P. 86.

13 Ibid. P.9.

14 Ibid. P. 5.

15 Ibid. P. 63-64.

${ }^{16}$ McKenna A. Bayle, Jurieu, and the 'Dictionnaire Historique et Critique'. By Mara van der Lugt. P. 698-699.

17 Van der Lugt M. Bayle, Jurieu and the Dictionnaire Historique et Critique. P. 67. 
The combination of "the view of the work as a whole" with careful attention to details enables to fully realize the author's aspiration "not to lose in depth what I gain in breadth"18, and also seems to be quiet fruitful. On the basis of this approach Mara van der Lugt opens a new dimension in the problem of relations between Pierre Bayle and his friend-adversary Pierre Jurieu (1637-1713) reflected in the Dictionary. Centering analysis of "Historical and Critical Dictionary" around the figure of Jurieu enables to reduce a wide scope to a circle of topics embraced in a single study. Thus, two research problems encountered by any scholar of Bayle's heritage are solved at the same moment: the tremendous volume of Bayle's opus magnus is handled within a valid frame given to the enormous mass of themes, concepts and persons mentioned in the Dictionary, and a new reading of Jurieu's presence in it is outlined. But that does not exhaust the list of the used approaches. The application of Bakhtin's methods to reading Bayle and tracing parallels between him and Fyodor Dostoyevsky will be definitely of interest to Russian readers. One more methodological principle of Mara van der Lugt's, which is, perhaps, not entirely original, but nonetheless productive, is offering a contextual reading of Bayle. Finally, the number of approaches discussed by Mara van der Lugt produces an impression that she attempts to mix a range of ways and existing methods of reading and interpreting Bayle, albeit not suggesting too much positively new. Criticizing and approving of different traits and sides of various theories, she intends to make a sort of a philosophical stone for reading Bayle out of already existing materials.

The structure of the monograph is quite traditional: it consists of an introduction, five chapters (the first of them outlining the methodology used, and the others - dealing with different Bayle's concepts), and a conclusion. Abundant annexes (focusing on persons and philosophical or religious currents mentioned in the book), which simplify the search for a wide variety of readers, conclude the work. However, its style as well as the idea and the design of illustrations deserve a special consideration. The monograph provides a baroque mixture of facts, texts, ideas, philosophy and history; the impression being increased by the multilingualism of the book written in English and interspersed with citations in French and - occasionally — in Latin and Italian ${ }^{19}$ (which may become a challenge for non-French-speaking readers, but definitely clarifies the apparatus as well as simplifies the reading for professionals making it more enjoyable). The idea of illustrating the work with texts evocative of Bayle's specifics and textual finding, produces an interesting effect, which is intensifiedby the multilingualism of the monograph. The largest group of illustrations given in the edition consists of the schemes of the Baylean "webs" made by the author, giving visual evidence to the ties between the articles of the Dictionary described in the text. An elaborated system of extensive notes complements the apparatus. In addition, written in a lively and figurative language, an emotionally-rich text conveys the author's sense of style and her deep involvement in the problems in question.

Bayle's Dictionary resembles a model of a human's mind with its complex system of linked ideas, where one idea may be put in many contexts, and such connections in the

18 Ibid. P. 8-9.

19 Studying the issues of multilingualism is a developing trend in the modern humanities. See, for example: Fyodorov S.: 1) The Identity processes in Medieval Wales Terminology, Discourses, and Context of Bilingualism // Dialog co vremenem - Dialogue with Time. 2017. Iss. 61. P. 25-39; 2) The Identity processes in Medieval Wales Terminology, Discourses, and Context of Bilingualism (Wealas-based nomenclature) // Ibid. 2018. Iss. 62. P. 48-61. 
Dictionary are represented by cross-references. The interest of the Enlightenment in the human being and modes of thinking makes such a comparison even more plausible.

Reading the whole Bayle's heritage is a great work itself. Cataloguing it makes a solid ground for any further research. Meticulous and careful text analysis with verification of different publications adds value to the study. All three features combined in one paper make it respectable at the very least. The research undertaken by Mara van der Lugt due to the thorough text analysis based on elaborated methodology is rich with new readings of Bayle's ideas and concepts. But this thorough reading has produced one more interesting effect which becomes more and more obvious while reading Mara's text.

It is not an infrequent situation when scholars dealing with texts of bright intellectuals of previous epochs subconsciously (or consciously) borrow some traits of style and method of theirhero. Indeed, the monograph "Bayle, Jurieu and the Dictionnaire historique et critique" to some extent resembles the Dictionary. The methods of addressing readers of van der Lugt and Bayle are rather similar. Mara makes her readers confuse in the Baylean webs just as Bayle does, and such structure of some chapters seems to demonstrate Bayle's specificity in the best way possible. Just as Bayle, Van der Lugt often digresses from the main subject to sketch the problems connected with the main issue making the picture multidimensional. Moreover, she lets her heroes speak from the pages of her own work: there are not only expositions of the Baylean texts, but also abundant citations in the source language. Such approach enables the texts in question to speak for themselves and gives the reader an opportunity to familiarize with Bayle from the suggested point of view. And the incompleteness of Mara's position stays only verbal, while the methodological approach of van der Lugt assists the reader in composing a solid image of the Baylean method and philosophical views. The uncertainty of the author's position is compensated by the end of the book with the sense of grasping of the whole picture of Bayle, his works and relations with the society (and Pierre Jurieu) Thus the monograph, complex and even complicated as it is, plays the role of a projector producing a hologram in the mind of the reader. Therefore, a sketch of Bayle's philosophy which van der Lugt refuses to draw ${ }^{20}$ nevertheless emerges in the reader's mind.. If we look at the question from this point of view, her refusal to specify and draw conclusions does not seem strange any more.

Besides familiarizing the interested audience with Bayle’s opus magnus, Van der Lugt enriches the Baylean historiography with the idea "that there are many kinds of Baylean influence, having multiplied with the number of readings of Bayle; that Bayle's role, far from being constant or static, is a layered, complicated, multiform collection - as intrinsically evasive as Bayle himself" 21 . An interesting problem is established - the problem of reading the elusive authors ${ }^{22}$, a very post-modernist one, dealing with the involving of the personality of the author in the process of the interpretation of his text.

The problem of intellectual discussions within the intellectual community is also raised , and it may be one of the most interesting sides of Mara's writing. Complexity, heterogeneity and polysemy of the debates among the early modern European scholars are vividly and skillfully outlined in the monograph. The author shows that the discussions were not based only on the philosophical views and theoretical constructions of those scholars, and that often personal problems and interpersonal relations meddled in

${ }^{20}$ Van der Lugt M. Bayle, Jurieu and the Dictionnaire Historique et Critique. P. 10.

21 Ibid. P. 13.

22 Ibid. P. 4, etc. 
and complicated the arguments. In this regard, Mara's subject area - once more - never comes out of date. Finally, these issues encourage the future analysis of the phenomenon of the Republic of letters both before and after the end of the seventeenth and the beginning of the eighteenth centuries.

This point permits to pass to several considerations concerning the ideas expressed in the monograph. Most of them relate to the marginal questions and have not been central for Mara van der Lugt, but provoke certain commentaries. The first of them is connected with the problem of continuity in the intellectual processes in early modern Europe, which is also tied with the issue of the historical writing in the seventeenth century. Mara does not neglect tracing the connection between Bayle's texts and his biography, including his flee to the Dutch Refuge and his personal tragedy of almost simultaneous loss of his father, brother and teacher. On the other hand, the absence of many outstanding historians both of the antiquity and the Renaissance, though noted, is not interpretated in the monograph. At the same time, in the process of contextualizing Bayle we meet such key figures of the early modern European historical writing as Scaliger, Saumaise, and Selden. But no ideas of erudition or of how the early modern European erudite discourse had contributed to the formation of Bayle as a scholar are proposed by Van der Lugt. The Republic of letters, as Mara van der Lugt argues, had neither geographical, nor temporal borders ${ }^{23}$; moreover, she insists (which is, however, disputable) that the idea of revision of the historical knowledge itself could emerge only when a vast material had been gathered. Yet the genetic relationship between the erudition and the early Enlightenment is almost absolutely ignored.

The analysis of Bayle's attitude towards the French erudites of the second half of the sixteenth and the first half of the seventeenth centuries would be interesting and productive as looking backwards and analyzing the tradition already existing by the time of a scholar's intellectual activity is no less, or even, perhaps, more important and fruitful than tracing links mostly between him and his contemporaries and the posterior tradition. For example, the legal terminology used by Bayle is underestimated by Van der Lugt: the work of a historian has been seen as analogous to the work of lawyers. Bayle couldn't have ignored the conception suggested by English antiquarians in the sixteenth century ${ }^{24}$, as he cited John Selden, but this subject is outside the researcher's scope. Furthermore, Van der Lugt's analysis of how Bauley used the apparatus and the system of cross-references does not demonstrate the innovativeness of his approach but proves that many thinkers of early modernity considered their works a whole entity, and linking them with a system of cross-references was part of their methods ${ }^{25}$. An interesting parallel drawn by Bayle between the scientific discussions and the warfare is also not, to my mind, fully examined, and is in need of a more comprehensive study as it is connected not only with the problem scientific debates. The work of a historian in Europe since the sixteenth century has been considered a noble occupation, respectable and worthy of being undertaken by noblemen ${ }^{26}$. And the idea that

${ }^{23}$ Van der Lugt M. Bayle, Jurieu and the Dictionnaire Historique et Critique. P. 79.

${ }^{24}$ Fedorov S. E. Antikvarnoe istoriopisanie: istoriia i sovremennost'v iakobinskoi Anglii. St. Petersburg, 2007; Terentyeva E. A. Discourse on the method of William Camden // Dialog co vremenem - Dialogue with Time. 2015. No. 51. P.300-309.

25 Terenteva E.A., Palamarchuk A.A. The Rise of National historical writing in France: Andre Duchesne and his historical methodology // Vestnik of Saint Petersburg University. History. 2015. Iss. 2. P. 80-92.

${ }^{26}$ Fyodorov S. Consuming splendor: society and culture in seventeenth-century England. By Levy Peck Linda // The Historical Journal. 2005. No.51(1). P.277-279. 
"if they exposed their hides to the point of a sword as to the point of a pen, surely they would be more peaceful" 27 , having been read in this context, may sound much more profound - as dealing with the criticism towards the nobility and dignity of the scholars in question. All these problems also lead to questioning Mara's insistence on a strict boundary between erudition and Enlightenment ${ }^{28}$.

In addition, another problem of genetic relationship in Bayle's heritage exists - concerning the dramatic story of his education. Van der Lugt mentions the fact of Bayle's three-year conversion to Catholicism connected with the education in the college more than once. And still it seems she does not even try to search for any traces of the Jesuit education received by Bayle - which is very unlikely not to have echoed in his future life and research - and does not take into account how effective the impact of the Jesuit pedagogy could be $\mathrm{e}^{29}$.

One more question may be put - pertaining to the statement of the research goals of the study - but more in the context of the future Baylean studies than as a criticism of the present work. Mara van der Lugt persistently places Bayle in the philosophical-theological context of the epoch, from the debates on the problem of sovereignty to the problems of faith and reason. But where is history? There is no analysis of the "historical" dimension of the Dictionary, which is entitled "Dictionnaire historique et critique", and thus the historical component is accentuated by the author. It would be very interesting to trace the peculiarities of the historical method of an intellectual sceptic such as Bayle, who showed certain adherence to the rationalism of the early modern epoch. Van der Lugt's concentration on philosophy incline leaves a large number of questions, such as what sources Bayle used, and what his method of criticizing them was. Van der Lugt aims to analyze Bayle's method, but not the historical one, but his method of debates. Even in discussing the sins of Th. de Bèze and the Pope Sixtus IV she underlines not how Bayle drew his conclusions but how he composed his critique of other points of view, without showing his own arguments. "Historian's enterprise of separating error from fact" ${ }^{30}$ is thus demonstrated in her monograph rather poorly (but it seems not to have been her goal, anyway). The approach to the analysis of Bayle's participation in the debates, which is essential for the research of Van der Lugt, is rather similar. She focuses not only on the content of the debates and quarrels, but on their specifics, their mechanisms, which is very interesting a research direction, and a rather fresh one. Interesting findings and conclusions concerning European intellectual history, the Republic of letters and the socio-cultural aspects of its history as well as the history of ideas are made.

Anyway, the expressed criticism is levelled mostly at the future prospects opened in the Baylean studies due to Mara van der Lugt's method - the prospects which are

27 Van der Lugt M. Bayle, Jurieu and the Dictionnaire Historique et Critique. P. 85.

28 See: Fedorov S. E.: 1) Antikvarnoe istoriopisanie: istoriia i sovremennost' v iakobinskoi Anglii. St. Petersburg, 2007; 2) The "British" History of William Camden // Istoriia - Elektronnyi nauchnoobrazovatelnyi zhurnal, 2016. Vol.7, iss.2; Pronina E. A. "Ottsy istorii" Frantsii i Velikobritanii: Andre Diushen i Uil'iam Kemden ( $\mathrm{k}$ voprosu o zarozhdenii natsional'nogo istoriopisaniia $\mathrm{v}$ stranakh Evropy rannego novogo vremeni) // Klio. No.2 (62). 2012. P. 86-88; Terenteva E. A., Palamarchuk A. A. The Rise of National historical writing in France: Andre Duchesne and his historical methodology // Vestnik of Saint Petersburg University. History. 2015. Iss. 2. P. 80-92; Terentyeva E. A. Discourse on the method of William Camden // Dialog co vremenem - Dialogue with Time. 2015. No.51. P.300-309.

${ }^{29}$ See, for example: Buttay F. Peindre en leur âme des fantômes: Image et éducation militante pendant les guerres de Religion. Rennes, 2018.

30 Van der Lugt M. Bayle, Jurieu and the Dictionnaire Historique et Critique. P. 99. 
definitely immense as the author herself points out both in the Introduction and in the Conclusion to her study.

The fact of the publication of a doctoral thesis in the Oxford Historical Monograph series testifies that the paper "engages the interest of a broad academic readership". Indeed, any researcher will find interesting scope in Mara van der Lugt's monograph - from ideas to methods of research. Rereading Bayle, the author contributes to the analysis of the Dutch Refuge and the Republic of letters, places the philosopher in the discussions on war, tolerance, and faith, as well as links his writings with the problems of history of the seventeenth century showing impressive diligence and sincere enthusiasm towards her object, without which such a research would have been impossible. Bayle's Dictionary is a "curiously organized end-product of a dynamic scholarly eclecticism" 31 , but these words can characterize Van der Lugt's research as well. Reading Mara van der Lugt's monograph is captivating as it involves immersion into the depth of Bayle's philosophical labyrinths and following the theoretical constructs of her own scholarly scrutiny.

\section{References}

Bernier J. Mara van der Lugt. Bayle, Jurieu, and the Dictionnaire Historique et Critique. Erudition and the Republic of Letters, 2018, vol. 3, iss. 2, pp. 232-234.

Buttay F. Peindre en leur âme des fantômes: Image et éducation militante pendant les guerres de Religion. Rennes, Presses Universitaires de Rennes, 2018, 371 p.

Collis K. Bayle, Jurieu, and the Dictionnaire historique et critique, by Mara van der Lugt. Intellectual History Review, 2018, vol. 28, no. 3, pp. 451-460.

Dear P., Shapin S. Nauchnaia revoliutsiia kak sobytie. Moscow, Novoe literaturnoe obozrenie Publ., 2015, 576 p. (In Russian)

Fyodorov S. E. Antique Historiography: History and Present 'in Jacobin England. St. Petersburg, St. Petersburg University Press, 2007, 42 p. (In Russian)

Fyodorov S.E. "Alternative" Courtyard in Early Stewart England: the Prince of Wales and his Entourage in 1605-1612. Problemy sotsial'noi istorii $i$ kultury Srednikh vekov i rannego Novogo vremeni. St. Petersburg, St. Petersburg University Press, 1996, no. 1, pp. 89-99. (In Russian)

Fyodorov S. The Identity Processes in Medieval Wales Terminology, Discourses, and Context of Bilingualism. Dialog co vremenem - Dialogue with Time, 2017, iss. 61, pp. 25-39. (In Russian)

Fyodorov S. The Identity Processes in Medieval Wales Terminology, Discourses, and Context of Bilingualism (Wealas-based Momenclature). Dialog co vremenem - Dialogue with Time, 2018, iss. 62, pp. 48-61. (In Russian)

Fyodorov S. The "British" History of William Camden. Istoriia - Elektronnyi nauchno-obrazovatelnyi zhurnal, 2016, vol.7, iss. 2. (In Russian)

Fyodorov S. Consuming Splendor: Society and Culture in Seventeenth-Century England. By Levy Peck Linda. The Historical Journal, 2005, no. 51(1), pp. 277-279.

Green M. Mara Van Der Lugt. Bayle, Jurieu, and the 'Dictionnaire Historique et Critique'. Renaissance Studies, 2017, vol. 32, iss. 4, pp. 667-669.

Irwin K. Bayle, Jurieu, and the Dictionnaire Historique et Critique by Mara van der Lugt (review). Journal of the History of Philosophy, 2017, vol. 55, no. 3, pp. 547-548.

Ivanova I. "History of Ideas" and "Civic Science": the Boundaries of Discipline in the Early New Age. Nauki o cheloveke: istoriia distsiplin. Eds A. N. Dmitriev, I. M. Savel'eva. Moscow, Higher School of Economics Press, 2015, pp. 53-73. (In Russian)

Matytsin A. Mara van der Lugt, Bayle, Jurieu, and the Dictionnaire Historique et Critique. H-France Review, vol. 17, no. 16, pp. 1-5.

McKenna A. Bayle, Jurieu, and the 'Dictionnaire Historique et Critique'. By Mara van der Lugt. History, 2017, vol. 102, iss. 352, pp. 696-699.

31 Ibid. P. 28. 
Pronina E. A. "Fathers of the History" of France and Great Britain: Andre Diushen and William Camden (on the Question of the Origin of National History in Early European Countries). Klio, no. 2 (62), 2012, pp. 86-88. (In Russian)

Repina L.P. Contexts of Intellectual History. Dialog co vremenem - Dialogue with Time, 2008, no.25-1, pp. 5-11. (In Russian)

Terenteva E. A., Palamarchuk A. A. The Rise of National historical writing in France: Andre Duchesne and his historical methodology. Vestnik of Saint Petersburg University. History, 2015, iss. 2, pp. 80-92. (In Russian)

Terenteva E. A. The Early Modern Genre of Cabinet in the Heritage of French erudites. Vestnik of Saint Petersburg University. History, 2018, vol. 63, iss. 1, pp. 80-92.

Terenteva E. A. Discourse on the Method of William Camden. Dialog co vremenem - Dialogue with Time, 2015, no. 51, pp. 300-309. (In Russian)

Van der Lugt M. Bayle, Jurieu and the Dictionnaire Historique et Critique. Oxford, Oxford University Press, 2016, 319 p.

Whatmore R. Bayle, Jurieu and the Dictionnaire Historique et Critique, by Mara van der Lugt. The English Historical Review, 2018, vol. 133, iss. 561, pp. 443-444.

Whealan R. Review: Bayle, Jurieu, and the 'Dictionnaire historique et critique' by Mara van der Lugt. The Modern Language Review, 2017, vol.112, no. 2, pp. 508-509.

Wootton D. The Invention of Science: A New History of the Scientific Revolution. New York, Harper Collins Publ., 2015, 769 p.

Статья поступила в редакцию 24 апреля 2019 г. Рекомендована в печать 2 декабря 2019 г.

Received: April 24, 2019

Accepted: December 2, 2019 